\title{
Örgütlerde Politik Davranışların Kariyer Planlama Üzerine Etkisi
}

\author{
The Effect of Political Behavior on Career Planning in Organizations
}

\author{
Yavuz DEMIREL ${ }^{*}$ \\ Erol TURAN** \\ Sefa ÇETIN ${ }^{* * *}$ \\ Derya DENGEL ${ }^{* * * *}$
}

\section{$\ddot{O} Z$}

Bu çalışmada, örgütlerde politik davranışlar ve bu davranışların kariyer planlama üzerine etkisi kavramsal olarak incelenmiştir. Örgütlerde bulunan bireylerin istekleri, hedefleri, beklentileri bulunmaktadır. Bu istek, hedef ve beklenti doğrultusunda da daha fazla kaynağa sahip olmak istemeleri, örgütün bütçesini, örgütün amaç ve hedeflerini, örgütün görev ve sorumluluklarını, alınan ücretleri, elde edilecek başarı ve meslekte yükselme durumlarının paylaşılması esnasında çalışanları karşı karşıya getirmekte ve çalışanlar tarafindan politik davranışlar sergilenmesi neden olmaktadır. Bu politik davranışlar ise aynı zamanda performans değerlendirme, ücret artışı ve terfi gibi çalışanın kariyer gelişimi açısından önemli olan insan kaynakları kararlarına etki etmektedir. Bu bağlamda insanların politik davranışlarla istediklerini elde etmesinin, örgüt içerisinde faaliyet gösteren diğer bireylerin kariyer planlaması ve davranışlarında değişikliklere yol açtığ sonucuna ulaşılmıştır. Tüm bu sonuçlara ulaşılırken literatür incelemesi yapılmış ve politik davranışlar ile kariyer planlaması arasındaki ilişki incelenmiştir.

\section{ANAHTAR KELIMELER \\ Örgüt, Politik Davranış, Kariyer Planlama, Politik Taktik}

\begin{abstract}
In this study, political behaviors in organizations and the effect of these behaviors on career planning are conceptually examined. Individuals in organizations have their aspirations, goals, and expectations. This desire causes confrontation between employees about; wanting to have more resources in the direction of expectations and goals, sharing budget of the organization, duty and goals of the organization, received payments and causing them to show political behaviors. These political tactics also affect human resource decisions that are important to an employee's career development, such as performance appraisal, wage increase and promotion. In this context, people achieving what they want through political behaviors has achieved the result of causing other individuals who work in the organization to change their career planning and behaviors. A literature review was conducted to reach all these results and a conceptual dimension was analyzing to relationship between political behavior and career planning.
\end{abstract}

\section{KEYWORDS}

Organization, Political Behavior, Career Planning, Political Tactic

\begin{tabular}{|c|c|c|}
\hline \multicolumn{2}{|c|}{ Makale Geliş Tarihi / Submission Date } & \multicolumn{1}{c|}{$\begin{array}{c}\text { Makale Kabul Tarihi / Date of Acceptance } \\
28.03 .2019\end{array}$} \\
\hline \multirow{3}{*}{ Atıf } & $\begin{array}{l}\text { Demirel, Y., Turan, E., Çetin, S., Dengel, D. (2019). Örgütlerde Politik Davranışların Kariyer Planlama Üzerine Etkisi. } \\
\text { Selçuk Universitesi Sosyal Bilimler Meslek Yüksekokulu Dergisi, 22 (1), 302-314. }\end{array}$ \\
\hline
\end{tabular}

\footnotetext{
${ }^{*}$ Prof. Dr., Kastamonu Üniversitesi İktisadi ve İdari Bilimler Fakültesi, ydemirel@kastamonu.edu.tr, ORCID: 0000-0003-3478-6307 *** Doç. Dr., Kastamonu Üniversitesi, İktisadi ve İdari Bilimler Fakültesi, eturan@ @astamonu.edu.tr, ORCID: 0000-0003-0343-7622

**** Doç. Dr., Kastamonu Üniversitesi, İktisadi ve İdari Bilimler Fakültesi, sefacetin@ kastamonu.edu.tr, ORCID: 0000-0003-0935-5097

***** Doktora Öğrencisi, Kastamonu Üniversitesi, İİBF, İşletme Anabilim Dalı, deryadengell@ gmail.com, ORCID: 0000-0003-3456-8502
} 


\section{GíRiș}

Örgüt olgusu, bireylerin gereksinimlerini kendi kendilerine gerçekleştiremeyecekleri düşüncesinin bir sonucudur. Genel olarak örgüt dendiğinde; iki veya daha çok kişinin ortak bir hedef için davranışlarını şekilsel yöntemlere göre düzenledikleri bir yapı akla gelmektedir (Karcioğlu ve Timuroğlu, 2004: 331). Örgütlerin tesadüfen veya rastgele oluşan topluluklardan farkı bir hedeflerinin olması ve bu konularda üst düzey bilgi birikimi ve tecrübeye sahip olmalarıdır. Yani bir araya geliş amaçları olanı gerçekleştirmektir (Malinowski, 1990: 22).

Yapılarına, temel amaçlarına ve üyelerinin duygusal durumlarına göre farklı örgüt türleri bulunmaktadır. Bu çalışmanın ana sorunsalı bağlamında önem arz eden ve çalışmanın esasını yakından ilgilendiren örgüt türü, üyelerinin duygusal durumlarına göre olan örgüt türleridir. Üyelerinin duygusal durumlarına göre örgütler de kendi içerisinde ikiye ayrılmaktadırlar. Bunlar; birincil örgütler ve ikincil örgütlerdir (Ertürk, 1995: 153). Birincil örgütler, grupta bulunan üyelerin karş1lıklı olarak birbirleriyle sürekli iletişim halinde olduğu, yaşam biçimlerini, tarzlarını örnek aldığı, grup içerisinde birbirlerine yaptırım gücü yüksek olan ve duygusal yönden birbirlerini tam olarak etkiledikleri örgüt biçimidir. Bu örgüt tipinde grup üyeleri birbirleriyle sürekli etkileşim halindedir ve birbirlerini fazlasıyla etkilemektedirler (Ertürk, 1995: 157). İkincil örgüt tipinde çok sayıda üyeden meydana gelen bir oluşum vardır, fakat birincil örgütlerde olduğu gibi birbirlerini doğrudan etkileme durumu pek söz konusu değildir. Bunun yerine örgüt üyeleri birbirlerini dolaylı yollardan etkilemektedirler (Tokat ve Aşkun, 2003: 22). Bunu sağlayan durum ise örgüt üyeleri arasında bulunan iletişimin son derece zayıf olmasıdır. Birlikte karar verilip oluşturulan kurallar vardır. İletişim çerçeveleri aşağı yukarı bellidir. Herkes kendi üzerine düşen görevi yapma eğilimindedir.

Genel olarak, örgüt, belirli bir içyapısı olan, özel hedeflere yönelen ve üyeleri tarafından bu hedeflerin gerçekleşmesine katkıda bulunulan somut bir toplumsal kümelenme biçimidir. Günümüzde örgütler insanların yaşamlarına devam etmek için kazanmaları gereken maddi ve manevi her türlü getiriyi elde edebilecekleri yapılar haline gelmişlerdir. Dışarıdan bakıldığ 1 kadar her şeyin kolay olmadı̆̆ etkileşim halinde olması beklenen bu yapılarda bireyler pek çok zaman diğer bireylerin menfaatleri pahasına bile olsa, kendi menfaatlerini gözetebilmek için politik davranışlardan kaçınmamışlardır.

Örgüt içerisinde insan kaynakları açısından da çok farklı durumlarla karşılaşılır. Bunlar; terfi, zam, ön planda ve popüler olma, hedeflere ulaşma, çıkarlarını gerçekleştirme gibi durumlardır. Bireyler özelliklede bu amaçlarını gerçekleştirebilmek için daha çok politik davranışlar sergilemektedirler.

Örgüt içerisindeki her çalışanın kendi amaçları doğrultusunda daha fazla kaynak ve güç elde etmek istemesi; gücün ve kaynağın, yetki ve sorumlulukların, maaş ve terfilerin paylaşılması konusunda çalışanları rekabete sürüklemekte ve bu da kaçınılmaz bir güç yarışı ortaya çıkartmaktadır. Hal böyle olunca bireylerde gücü elde etmek ve kullanmak için örgüt içerisinde çok farklı davranışlar sergilemektedirler. Bu davranışlar; kişinin etrafına, yaşamına, geleceğine kadar her şeyine yön vermektedir.

Tüm örgütlerin ya da tüm bireylerin aynı seviyede ve aynı koşulda politik davrandıklarını ifade etmek mümkün değildir. Bu durum, bireyden ve örgütten kaynaklanan birçok faktöre bağlı olarak değişiklik göstermektedir. Politik davranışlar sonrasında hedeflenen kazanımlar elde edilirse bu davranışların görülme sıklığında da birtakım değişiklikler oluşmaktadır. İşte bu davranışların ne olduğu ve kariyer planlamasını nasıl etkilediğinin önemi bu aşamada ortaya çıkmaktadır.

$\mathrm{Bu}$ açıklamalardan hareketle çalışmanın amacı; bireylerin örgüt içerisinde sergiledikleri politik davranışların kariyer planlaması üzerine etkilerini bir bütün olarak ele almaktır. Bu bağlamda çalışmanın ilk kısmında örgüt ve politik davranışlar ele alınmakta, ikinci kısımda kariyer ve kariyer planlaması incelenerek daha sonra örgütlerde politik davranışların kariyer planlaması üzerine etkisi teorik çerçevede incelenmektedir.

\section{1. ÖRGÜTLER VE POLITTIK DAVRANIŞ}

Örgütlere hangi gözle bakılırsa bakılsın, hangi anlam verilirse verilsin, sonuç itibariyle her örgüt politik bir yapıdır. Başka bir deyişle örgüt adı verilen yapı içinde bireyler (örgüt üyeleri) çeşitli yol ve metotlarla birbirlerini etkilemek ve belirli yönde davranışa sevk etmek çabası içindedirler (Koçel, 2001: 454). Örgüt üyelerinin güç kazanma ve güç kullanma yönündeki bu çabaları örgüt içi politikayı (organizational politics) oluşturmaktadır. Bu bağlamda örgüt içi politika, bir örgüt içinde çalışan çeşitli açılardan farklı (otorite, amaç, kişilik vs.) fakat başarı açısından birbirine bağlı kişi veya grupların, amaçların, yol ve yöntemlerin ve süreçlerin belirlenmesinde kullanılan örgütsel karar mekanizmasına kendi görüşlerini hâkim kılmak için, sahip oldukları gücü kullanarak birbirlerini etkileme sürecidir (Miles, 1980: 54).

Bireylerin örgüt içerisinde amacını, beklentisini, isteğini yerine getirmek ve kendi kazanımları doğrultusunda da yaptıkları her bir bilinçli davranış politik davranış olarak düşünülebilir (Bursalı, 2008: 25). Politik eylemler gücün korunmasını sağlamak, tekrar üretime geçirebilmek ve bir çıkar durumu ortaya 
çıkarabilmek için yapılan sosyal içerikli ve iletişime dayalı davranışlardır. Yaşanılan çağda örgütler sürekli değişime ve gelişime mecbur kaldığı için politik davranışlar kaçınılmaz hale gelmektedir.

Örgütte bulunan bireylerin istek, hedef ve beklentileri sonucunda daha fazla güce sahip olma istekleri örgütün bütçesini, örgütün amaç ve hedeflerini, örgütün görev ve sorumluluklarını, alınan ücretleri ve elde edilecek başarı ve meslekte yükselme durumlarının paylaşılması esnasında çalışanları karşı karşıya getirmektedir. Bu sebeple ortada bulunan gücü kontrol etme, yönetme, daha fazla getiri sağlama gibi durumlar ortaya çıkmaktadır. Hal böyle olunca da örgütler politik davranışlara tam anlamıyla açık yapılar haline gelmektedir.

Örgütlerde politika kavramı ilk olarak sanayileşmenin başladığı dönemlerde Max Weber tarafından ele alınmıştır. Weber'in idealize ettiği örgütlerde bütün ciddi politik kararlar herkes tarafından ortak bir şekilde alınmakta ve idarenin sadece kararları hazırlama ve yürütme fonksiyonu söz konusudur (Kundakçı, 2016: 125). Bununla birlikte pek çok yönetim bilimci örgütlerde politik davranışlara pejoratif bir yaklaşım sergilemişler ve bu çerçevede politik davranışla ilgili çeşitli tanımlamalar yapmışlardır. Bazıları, politikayı gücün bireysel yararlar sağlamak amacıyla kurum tarafindan kavramsal olarak onaylanmamış bir süreç olarak değerlendirmişlerdir (Farrell ve Petersen, 1986; Murray ve Gandz, 1980). Benzer şekilde, politika başkalarını etki altına alabilmek için gücü kullanma yöntemi olarak görülmüş (Pettigrew, 1973; Tuschman, 1977); bazılarına göre ise politika örgüt için olumlu ve olumsuz sonuçlar yaratabilen bir süreçtir (Allen ve diğ. 1979: 78). Mintzberg (1983) örgütlerde politikayı, ayrıştırıcı, resmi olmayan ve örgüt içerisinde hoş görülmeyen davranışlar olarak ele almış; Ferris, Fedor, Chachere ve Pondy (1989) ise başkalarının yararına olmayan kısa süreli veya uzun süreli bireysel amaçları en üst seviyede gerçekleştirebilmek için taktiksel olarak planlanmış karş11ıklı etkileşim süreci olarak değerlendirmişlerdir.

Örgütlerde politik davranışlar ve bu davranışların örgütlerin işleyişine çeşitli açılardan etkisine yönelik çok sayıda çalışma yapılmış ve bu çalışmalar sonucunda farklı boyutlarda ölçekler geliştirilmiştir. İlgili literatürde ön plana çıkan çalışmalar ve ulaştıkları bulgular aşağıda Tablo 1'de özetlenmektedir.

Tablo 1. Politik Davranışların Örgütün İşleyişine Etkisine Yönelik Yapılan Çalışmalar

\begin{tabular}{|c|c|c|}
\hline Çalışma yapan araştırmacılar & Geliştirilen ölçek & Bulgular \\
\hline $\begin{array}{l}\text { Allen, R. W., Madison, D. L., } \\
\text { Porter, L. W., Renwick, P.A. ve } \\
\text { Mayes, B. T. (1979) }\end{array}$ & Politik taktik taksonomileri & $\begin{array}{l}\text { Çalışmada politik davranışlar } \\
\text { "başkalarına saldırma ya da onları } \\
\text { suçlama, bilgi kullanma, izlenim } \\
\text { yönetimi, kendi fikirleri için destek } \\
\text { sağlama, başkalarını övme ve göze } \\
\text { girme, güç koalisyonları ve güçlü } \\
\text { ittifaklar, güçlü olanlarla ilişki } \\
\text { kurma ve zorunluluk yaratma" } \\
\text { boyutları } \\
\text { sinıflandırılmıştır. }\end{array}$ \\
\hline $\begin{array}{l}\text { Kipnis, D., Schmidt, S. M. ve } \\
\text { Wilkinson, I. (1980) }\end{array}$ & $\begin{array}{l}\text { Politik Örgütsel Etkileme } \\
\text { Stratejileri Ölçeği }\end{array}$ & $\begin{array}{l}\text { Çalışmada politik taktikler, "baskı } \\
\text { uygulama, üst yönetimi arkasına } \\
\text { alma, karşılıklı çıkar gözetme, } \\
\text { koalisyon, göze girmeye çalışma, } \\
\text { mantıkla ikna etme, yaptırım ve } \\
\text { engelleme" olarak belirlenmiştir. }\end{array}$ \\
\hline $\begin{array}{l}\text { Mayes, B. T. ve Ganster, D. C. } \\
\text { (1988). }\end{array}$ & Kişisel Politik Eylemler Endeksi & $\begin{array}{l}\text { Tek boyutlu olarak uygulanan } \\
\text { ölçekte kişinin çıarlarına hizmet } \\
\text { eden on yedi maddelik çeşitli } \\
\text { taktikleri belirlenmiştir. }\end{array}$ \\
\hline Yukl, G. ve Falbe, C. M. (1990). & Politik taktik ölçeği & $\begin{array}{l}\text { Örgütlerde politik taktiklerin } \\
\text { boyutları "rasyonel ikna, karşılıkl1 } \\
\text { iyilik, göze girme, baskı uygulama, } \\
\text { koalisyon kurma ve üstü etkileme, } \\
\text { değerlere ve inançlara yönelme ve } \\
\text { danışma" olarak belirlenmiştir. }\end{array}$ \\
\hline
\end{tabular}




\begin{tabular}{|c|c|c|}
\hline Wayne, S. J. ve Ferris, G. R. (1990). & Politik davranışlar ölçeği & $\begin{array}{l}\text { Örgütlerde politik davranışların } \\
\text { boyutları "kişi odaklı, iş odaklı ve } \\
\text { süpervizör odaklı" olarak } \\
\text { sinıflandırılmıștır. }\end{array}$ \\
\hline $\begin{array}{l}\text { Zanzi, A., Arthur, M. B. ve Shamir, } \\
\text { B. (1991). }\end{array}$ & Politik taktik ölçeği & $\begin{array}{l}\text { Bu çalışmada iki politik taktik } \\
\text { boyutu bulunmuştur. Bunlar } \\
\text { "hiyerarşik taktikler" ve "ağ kurma } \\
\text { taktikleri" dir. Bu boyutlar iki ayrı } \\
\text { ölçek olarak belirlenmiştir. } \\
\text { Hiyerarşik taktik kişinin statü veya } \\
\text { güç kazanmak için açık ve } \\
\text { doğrudan yaptığı girişimlerdir. Ağ } \\
\text { kurma taktikleri ise belirgin } \\
\text { olmayan ve ortak çıarlara hitap } \\
\text { eden taktikleri ifade etmektedir. }\end{array}$ \\
\hline Sonaike, K. (2013). & $\begin{array}{l}\text { Gözlemlenen ve kişisel olarak tecrübe } \\
\text { edilen politik davranışlar ölçeği }\end{array}$ & $\begin{array}{l}\text { Bu çalışmada politik taktiklerin } \\
\text { boyutları olarak, "karar vermeyi } \\
\text { etkileme, vazgeçilmezliği attırma, } \\
\text { merkezileşmeyi arttırma, güçlü } \\
\text { yöneticilerle ilişki kurma, koalisyon } \\
\text { kurma ve yönetme" olarak } \\
\text { belirlenmiştir. }\end{array}$ \\
\hline
\end{tabular}

Politik davranış için yapılan tanımlamaların ortak özelliği bu davranışların bireylerin yararlarına öncülük etmesi, elde edilmek istenen sonuçlara daha çabuk ulaşabilmesi için çalışana yardımcı olması, ancak kurum tarafindan doğru karşılanmamasıdır (İslamoğlu ve Börü, 2007: 142). Örgütlere ne açıdan bakılırsa bakılsın birer politik yapılardır. Farkında olmadan yapılan ve kendi çıkarını gözetmeyen, başkalarının yararını düşünerek yapılan davranışlar politik davranış kavramıyla açıklanamamaktadır.

Örgütlerde politik davranışlar kaçınılmazdır. Çünkü ortada bir güç vardır. Otorite boşluğunu fırsat bilen kişiler bu gücü kullanma ve buldukları her fırsatta politik davranış sergileme eğilimindedirler. Bu eğilimi ise başkalarını etkileri altına alarak amaçlarına ulaşma ve çıkarlarını gerçekleştirme durumu bireyin, bulunmuş olduğu örgütün etki ve başarı durumu hakkında bilgi edinmek için önem arz eden bir faktördür. Politik davranışlar örgütlerde alınan kararların nasıl alındığ 1 , örgüt içerisinde çalışan kişilerin yatay ve dikey olarak karşılıklı bir şekilde birbirlerini nasıl etkiledikleri, nasıl motive ettikleri, nasıl sadakat duygusunu ve bağlılıklarını geliştirdikleri, örgütte bulunanların kimleri neden destekleyip desteklemedikleri, örgütteki bireylerin nasıl bir iş birliği yaptığı, örgütün amaç ve hedefleri için uygulanan taktiklerin başarılı bir şekilde uygulanıp uygulanmadığını göstermek açısından son derece önemlidir.

Politik davranışların özünde yatan başkalarını etkileyerek hedeflenen amaca ulaşma ve bireysel çıkarlarını yerine getirme isteği, kişilerin, örgütlerin etki durumlarını ve başarı seviyelerini anlama konusunda oldukça önemlidir. Politik davranışlar, örgütlerde kararların nasıl alındığını; çalışanların, yöneticilerin ya da aynı iş kolundaki kişilerin faydalarını nasıl maksimize ettiklerini; bazı çalışanların kurumdaki kimi kişi ve gruplara yarar sağlarken, diğerlerine neden yarar sağlamadıklarını; üst yöneticilerin, astların ya da meslektaşlarının işbirliği ve faydalarını nasıl elde ettiklerini, çalışanlarını motive etme ve ekstra çaba sarf etmeleri konusunda nasıl girişimlerde bulunduklarını; örgütteki strateji ve politikaların başarılı bir şekilde gerçekleştirip gerçekleşmediğini vb. göstermesi bakımından anlam ve önem kazanmaktadır (Bursal1, 2008: 75). Bu çerçevede hem örgütün hem de örgütte çalışan kişilerin kendi menfaatlerini korumak ve amaçlarını gerçekleştirmek için, 'rasyonel kararları' doğrultusunda rasyonel olmayan şekilde davranış sergilediklerini söylemek yanlış olmayacaktır. Aynı zamanda kendisi ve menfaatleri söz konusu olduğu anlarda oldukça akılcı ve rasyonel bir şekilde hareket eden iş gücü ya da örgütlerin, ilk olarak, kendi menfaatlerini önemsedikleri ve başkalarının zararı pahasına bile olsa, politik davranışlar sergiledikleri gözlemlenmektedir. Çünkü diğer kişilerin tutum ve davranışlarını etkilemedeki hedef hem örgütün hem de örgütte çalışan kişilerin gereksinimleriyle doğru bir şekilde eşleşmektedir (Hellriegel ve diğ. 2001: 223).

Yöneticiler, örgüt içerisinde çalışan kişiler ya da kurumların davranış ve hareketlerine yön vermek istediklerinde bir hedef belirlemek ve buna göre yöntemlerini seçmek zorundadırlar (Peled, 2000: 27). Miller ve Kurchner-Hawkins (2004) araştırmalarında politikalar, örgüt içerisindeki kişilerin günümüzün karmaşık dünyasında amaçlarını gerçekleştirerek ve gücü doğru bir biçimde kullanarak, kurumu ve diğer kurum çalışanlarını etkilemek için, ayırt etmeleri gereken bir yetenekler sistemini oluşturmaktadır sonucuna 
varmışlardır. Bu yetenek sistemi ise, üstlerin ve astların meslektaşlarıyla, diğer personellerle, müşterilerle ve yöneticileriyle bireysel ilişkilerini ustaca yönetme becerisine bağlanmaktadır

Örgüt çalışanlarının performanslarında bazen bir düşüş meydana gelebilir ve bu sebeple oluşabilecek kötü sonuçları en aza indirmek, bazen de işleriyle ilgili olmayan davranışlarının onaylanması için destek sağlamak ve hedefledikleri fakat örgüt çalışanlarının performansıyla fazla ilgisi bulunmayan sonuçlar elde etmek için kendilerine verilen desteği artırma açısından çeşitli arayışlara girişebilirler. Örgütlerde bu şekilde oluşan politik davranışlarda bulunmaktadır.

\section{1. Örgütlerde Politik Davranışın Nedenleri ve Ortaya Çıktığı Alanlar}

Bir kurum kurulduğu ve faaliyetlerine başladığı andan itibaren, içerisinde bulundurduğu 'insan' öğesinden ötürü politik aşamaların etkisi altında kalmaktadır. $\mathrm{Bu}$ sebeple kurumda yer alan tüm alanların ve gerçekleştirilen her çeşit faaliyetlerin bireylerin politik davranışlarından kaynaklandığ ve bireylerin politik davranışlarına yön verdiği söylenebilir. Örgütlerde politik davranış durumlarının çok çeşitli nedenler olabilir. Bu nedenlerin altında yatan farklı ortamlar ve faaliyetler şu şekilde özetlenebilir (Murray ve Gandz, 1980: 17);

Örgütlerde politik davranış durumlarıyla en çok karşılaşılan alan terfilerdir. Kurum içerisinde çalışan kişiler kariyer planlamalarını gerçekleştirebilmek ve hedefledikleri terfileri alabilmek amacıyla, örgüt içerisindeki diğer çalışanlarla rekabet etmek durumunda kalırlar. Bu durumda ise birbirleriyle rekabet eden pek çok çalışanın hedefine ulaşabilmek için politik davranışlar sergilemesini ve güce sahip üst yöneticilerin de kendi menfaatleri doğrultusunda 'adam kayırmacılık' yapma durumları ortaya çıkmaktadır.

Çalışanlar şahsi çıkarlarına ulaşmak adına onlara destek verecek diğer kişiler karşısında onlara iyi görünmek için farklı şekilde politik davranışlarda bulunabilirler. Bu durum, çalışanların kendilerini çok farklı göstermelerine ve bazı olayların ya üstünü kapatmaya ya da çarpıtmalarına sebep olmaktadır.

Örgütte gerçekleştirilen faaliyetlerde yüksek risk durumunda olan faaliyetler daha fazla politik davranışlara açıktır. Yüksek risk durumunda olan faaliyetlerin yönetimi, kazanc1, işleyişi daha zor ve yüksek kazançlı olacağından bu faaliyet alanında çalışanların sayısı ve faaliyetler çeşitlenecektir. Kurumlarda çeşitli birim ve departmanlar arasında güç paylaşımı, gücü yönetme gibi bazı durumlara bağlı olarak ortaya çıkabilecek uyuşmazlıklar politik davranışları kaçınılmaz kılmaktadır.

Ellerinde bulunan kaynak azlığı bu kaynaklara olan ilgiyi ve bu kaynaklara ulaşmaya çalışan kişi sayısını artırmaktadır. Kaynak miktarı ve ulaşmaya çalışan kişi sayısında negatif bir korelasyon vardır. Kaynak yetersizliği bu kaynağı elde etmeye çalışan kişiler arasında birbirinden farklı politik girişim ve davranışlara yol açacaktır.

Politik davranışların altında yatan nedenler aşağıdaki şekilde gösterilmiştir.

\section{Şekil 1:Örgütlerde Politik Davranışın Nedenleri}

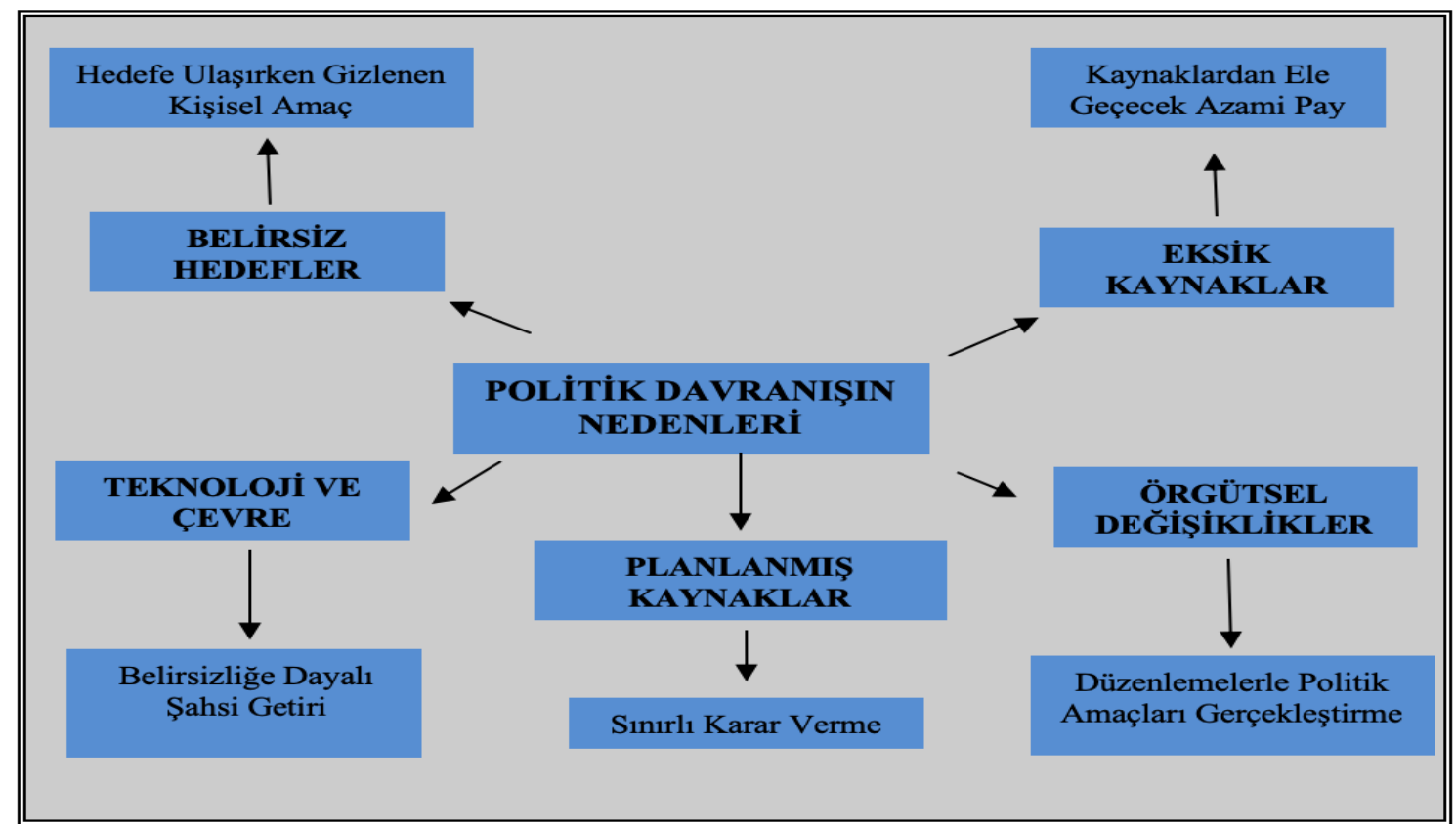

Kaynak: Mayes ve Allen (1977)'den uyarlanmıştır. 
Şekil 1'de görüldüğü üzere, örgütte sergilenen politik davranışlar, kişisel ve örgütsel sebeplerden kaynaklanmaktadır. Teknoloji ve çevrenin neden olduğu belirsizlik, üyeleri bu belirsizliklere dayalı olarak kişisel getiri elde etmeye yönlendirebilecektir. Aynı şekilde bu belirsizlikler bireyin gizlemiş olduğu kişisel amaçlarını gerçekleştirme bakımından gerekçe oluşturabilecektir. Bunların yanında eksik kaynaklar, örgütsel değişiklikler ve planlanmış kaynak kullanımının yol açtı̆̆ı sınırlı karar verme süreçleri gibi örgütsel nedenler bireyleri politik davranmaya yönelten nedenlerdendir.

Politik davranışların altında yatan en önemli hususlardan biri "güç" elde etmedir. Kuşkusuz, güç insanlık tarihinin en eski olgularından bir tanesidir ve en fazla başvurulan olgudur. Her örgüt, her kurum, her şirket, her devlet bu gücü tüm tarih boyunca elde etmeye ve elde ettikten sonrada elinde tutmaya çalışmıştır. Çünkü güçlü olmak ve istediklerini gerçekleştirmek hususunda rakiplerine karşı çok büyük bir üstünlük ve avantaj sağlar. Bu yüzden gücün kazanılması bağlamında da politik davranışlara başvurulması kaçınılmazdır. Örgütlerde çalışanların içinde yer aldıkları farklı girişimler, onlara çeşitli kazanımlar, kaynaklar ve avantajlar sağlayacağı için çalışanların bu oluşumlar içerisinde yer almayı hedeflemeleri, onları politik davranışlara sürüklemektedir (Bursal1, 2008: 82).

\subsection{Politik Taktikler}

Politik davranışlar örgütte örgütün kabul edilen davranışlarıyla örtüşmeyebilir. Kişinin yalnızca kendi çıkarlarına hizmet edebilir, örgüt hedefleri gözetilmeyebilir hatta örgüt hedefleriyle ters düşse bile yapılabilecek olan davranışlardır. Politik davranışların bazı farklı etkileme biçimleri bulunmaktadır. İnsanlar bu tip davranışlarda bulunurken farklı yöntem ve taktiklere başvurarak karşısındakini, astını veya üstünü etkisi altına almaya çalışmaktadır. Bu etkiye alma taktiklerinde başarılı olursa eğer elde etmek istediği terfi, zam, güç, psikolojik üstünlük, popülarite gibi kazanımları elde eder. Hatta bazı durumlarda yöneticileri bile yerinden edebilir (Kipnis ve diğ. 1980: 450).

Örgütlerde politik davranışların bazı yöntemleri şu şekillerde belirlenebilir:

Destek oluşturma yöntemi en s1k başvurulan yöntemlerden biridir. Çünkü politik davranışlarda çevredekilerin desteğinden faydalanma asıl amaçtır (Ceylan, 2004: 75). Bu taktiği uygulayan çalışan kendi amaçlarına ulaşabilmek ve isteklerini gerçekleştirebilmek amacıyla etrafında bulunan ast, üst veya herhangi diğer çalışanların desteğinden yararlanır. Diğerleriyle fikir birliğine vararak öneri, istek ve şikâyetlerinin dikkate alınmasını sağlar.

Kendini fark ettirme yöntemi, bir örgüt üyesinin kendi amaçları ve istekleri için etki yaratabilmek adına kendini olduğundan daha farklı göstermesidir (Judge ve Bretz Jr., 1994: 47). Özellikle iş konularında karşısındakilere daha bilgili, yetkin, hünerli, sözel-dilsel zekâsını yüksek göstermek asıl amaçtır. Aslında kişi için ortada böyle bir durum yoktur. Hatta bir noktadan sonra kişi buna kendisi bile inanıp, bu duruma kendisini fazlasıyla kaptırabilir. Bu davranışlar sergilendikten sonra asıl amaç olan performans değerlendirme, işe alınma veya terfi gibi durumlarda başarılarının mutlaka üstlerinin haberlerinin olmasını isterler ve bunu bir şekilde gerçekleştirirler. Aynı durum tam tersi içinde geçerlidir. Başarısızlık, hata, eksiklik, beceriksizlik gibi durumlarda ya bunları önemsiz göstermeye çalışırlar ya da üstünü örtmeye çalışırlar.

Göze girme yöntemi, örgüt üyesinin kendini amaçlarını gerçekleştirebilecek olan kişiye daha çekici, iş bitiren biri olarak göstermek şeklindeki giriştiği çabadır (İslamoğlu ve Börü, 2007: 137). Amaçlanan şey karşısındakiyle ortak bir nokta bulup bir bağ kurarak karşısındakinin dikkatini çekmektir. İstediklerini gerçekleştirebilmek için karşısındaki kişinin mutlu, keyifli, sakin olduğu zamanları bekleme davranışı da gösterebilir. Hedef kişiyi övebilir, hedef kişiye kendini özel ve değerli hissettirir.

Diğer bir yöntem üst makama başvurmadır. Üst makama başvurma yöntemini uygulayan üye, etkilemek istediği kişi için kurumun daha üst makamlarındaki ilişkilerini araya sokarak karşısındaki bireyin isteklerini gerçekleştirmesini sağlamayı amaçlar (Ceylan, 2004: 79). Uygulanan yöntem hedeflediği kişiyi çok ciddi bir şekilde baskıya alarak isteklerini yerine getirmeye zorlamaktadır. Ancak isteklerin hedeflenen kişi tarafindan gerçekleştirilmediği durumlarda üst makamlardan yaptırımla karşılaşabilir. Buna benzer bir taktik ise mübadele taktiğidir. Mübadele taktiğine başvuran birey belli ya da gizli şekilde karşısındaki çalışana, "istediklerimi yaparsan ben de seni ödüllendiririm" mesajını gönderir. Bu ödül ise genelde hedefteki kişinin talebini yerine getirmek şeklinde olabilir. Bu yöntemin uygulayıcısı olan birey hedeflediği çalışan için daha önce gerçekleştirdiği bir talebi de anımsatabilir, yani bu yönteme başvurulmasında daha önceden hedefteki bireye karşı geçekleştirilen yatırımlar da oldukça önem kazanmaktadır (O'Neil, 2004: 134). Bu yöntem, her şey karş1ıklıdır prensibi üzerine kurulmuş bir yöntemdir. Ödüllendirme isteğin gerçekleşip gerçekleşmemesine bağlıdır. Farklı bir şekliyse daha önceden hedef kişi için yapılan iyilik üzerinden gidilmesidir. Bu durumdaysa bir nevi geçmiş hatırlatılarak hedef kişiye mesaj verilir. 
Örgütlerde politik taktiklerden bir diğeri mantıkla ikna yöntemidir. Bu yöntem karşısındaki çalışana istediklerini gerçekleştirebilmek için mantıksal yol ve yöntemler kullanarak onu razı etme çabasıdır (McFarland ve diğ. 2002: 397). Kendini haklı çıarabilecek somut gerçekler öne sürer ve kendini haklı gösterebilmek için elinden geleni yapmaya çalışır. Hedeflenen kişinin zihninde aynı fikri inşa etmeyi başarabilirse kullanmış olduğu yöntemde başarıya ulaşabilir (Yukl ve Falbe, 1990: 132-140).

Örgütlerde söz konusu olan bu politik davranışlar ve bunlara bağlı olarak geliştirilen politik yöntemleri güdüleyen faktörler Şekil 2'de yer almaktadır.

\section{Şekil 2:Politik Davranışları İçeren Faktörler}

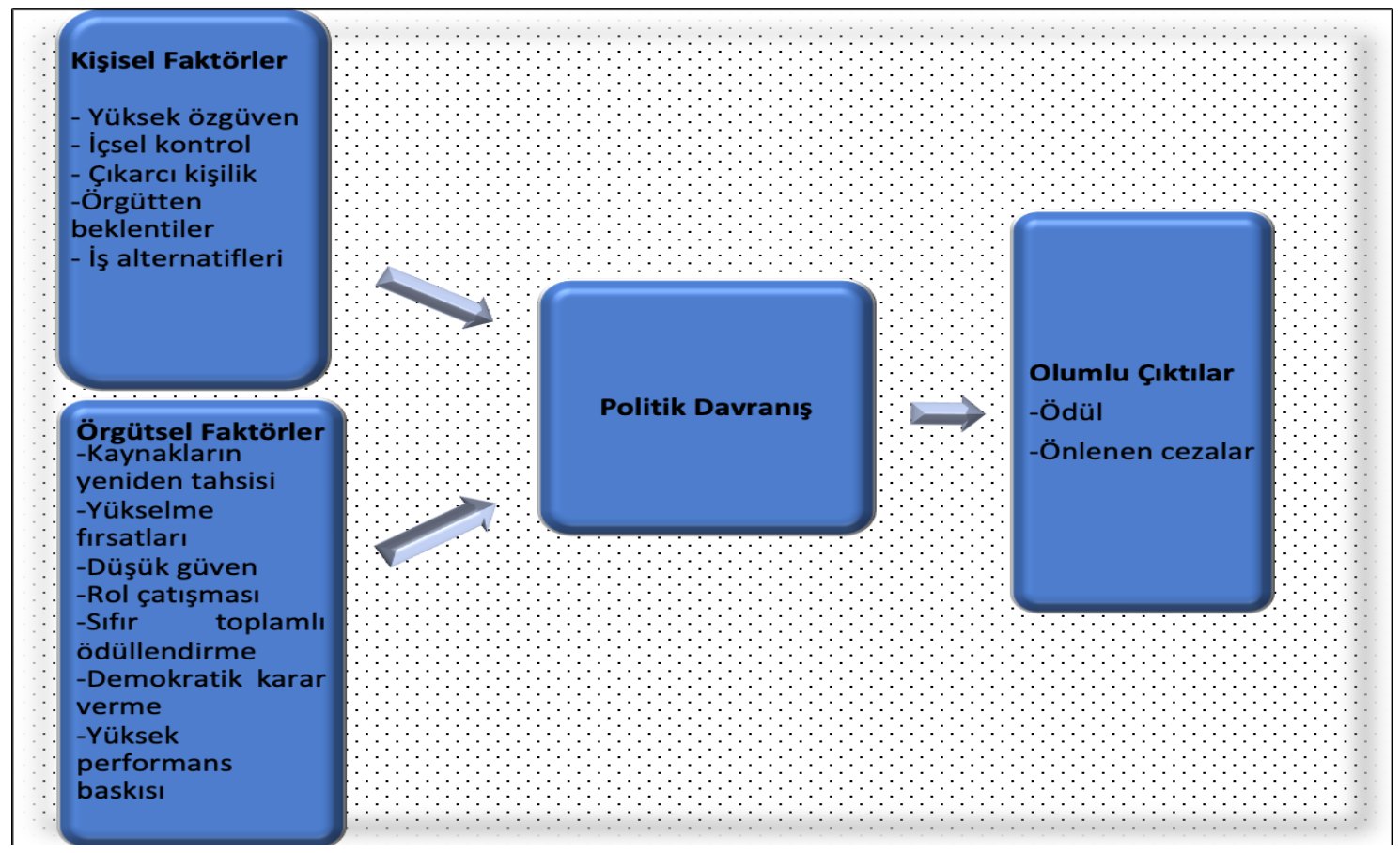

Kaynak: Robbins, S. P. ve Judge, T. A. (2017). Organizational Behavior, Pearson, Boston.

Politik davranışları güdüleyen faktörler, kişinin kendisinden veya örgütün yapısından kaynaklanabilir. Yüksek özgüven, çıkarcı kişilik, kişisel hedefleri örgütün hedeflerinden üstün tutma ve başka iş alternatiflerinin mevcudiyeti politik davranışları güdüleyen kişisel faktörler arasındadır. Örgütün yapılanmasından kaynaklanan faktörler ise, örgüt kaynaklarının tahsis biçimi, örgütte yükselme süreci, örgütsel güvenin düşüklüğ̈̈ ve çalışan üzerindeki yüksek performans baskısı kişileri politik davranışlara yönlendiren faktörler arasındadır. Kuşkusuz, bir örgütte bazıları daha fazla politik davranışlarda bulunurlar. Çünkü bu bireyler kişilerarası etkileşimleri daha iyi okuyabilmekte ve davranışlarını kişisel avantaj elde edecek şekilde, duruma uygun sergileyerek bu politik davranışlarından dolayı ödüllendirilebilmekte veya en azından örgütsel birtakım yaptırımlardan kurtulabilmektedirler (Robbins ve Judge, 2017: 475).

\section{2. ÖRGÜTLERDE KARIYYER PLANLAMA}

Kariyer kavramı en genel biçimiyle; bireylerin benzer veya farklı örgütlerde gerçekleştirmiş olduğu faaliyetlerle ve edindiği tecrübelerle birlikte elde etmiş olduğu gelişim şeklinde tanımlanabilir (Baruch ve Maury 2001: 360). Kariyer olgusu ve onun idare şekli, bireysel bir sorumluluk taşımakla beraber faaliyetlerde devam eden bu işleyişe dahil olmaktadır. Örgütsel bağlamda kariyer yönetimi çalışanın gereksinimlerini karşılamak ve kariyerindeki beklenti ve amaçları gerçekleştirmeleri için yapılması gerekeni planlama, taktikleri belirleme ve gerçekleştirme süreci (Budak ve diğ . 2001: 122) veya çalışan bireylerin kariyer hedefleri ile kurum veya örgütün amaçlarını ortak bir noktada birleştirmek için genellikle yönetici ve amirlerin kullanacağı taktiklerdir (De Cenzo ve Robbins, 1988: 122). Bu çerçevede örgütsel kariyer yönetimi esas olarak bireyin geleceğe dair mesleki yaşamını planlama süreci olarak belirlenebilir.

İster özel, isterse kamu örgütlerinde kariyer planlaması ve bunun uygun bir biçimde yönetilmesine azami derecede önem verilir. Bunun başlıca sebebi ise çalışanın isteği, mesleki doyumu ve çalıştığı örgüte bağl1 kalması temeline dayanır. Kişi hedeflerini gerçekleştirmede örgütün faydalı olacağına, o örgüte bağlı olup 
çalışmakla istediği hedefe, imkanlara ve kariyer hedefine ulaşacağına inandığında örgütle iş birliği yapar. Bu olumlu bağlılık ilkesi ile bağdaştırılabilir. Hedeflerine ulaşmasında örgüt elinden tutacak, birey hedefine ulaşırken kendi bilgi birikimini, gücünü, emeğini ve zamanını örgüt için harcayacaktır. Bu nedenle kariyer yönetimi sürekli bir çaba ve uğraş gerektiren bir alandır. Astların kariyer beklentileri ve amaçları etkili ve iyi bir iletişim sisteminin başarısıyla doğru orantılıdır.

Örgütlerde kariyer yönetiminin çeşitli hedefleri söz konusudur. Bunlar, örgütün yönetimin devamlılı̆̆ına olan gereksinimini sağlamak, çaba gösteren ve kendini vererek çalışan tüm personele yetenekleriyle eş değer seviyede sorumluluk seviyesine yükseltecek eğitim ve yöntemleri vererek tecrübe kazandırmak, yetenek ve ilgileri ölçüsünde potansiyele sahip çalışanlara hedefleriyle paralel ve örgüt içerisinde başarılı bir kariyer hayatına sahip olabilmeleri için gereken rehberliği vermek, yöntemlerini öğretmek ve odaklanmayı sağlamaktır (Canman, 1995: 75). Faaliyetler bağlamında kariyer yönetimi süreci bir örnek açısından düşünüldügünde, dört basamaklı bir yaklaşımla incelenmesinin uygulamayı fazlasıyla kolaylaştıracağı düşünülmüştür. Kariyer yönetimi dört başlıkta irdelenebilir: Kariyer planlamasına dahil edilecek çalışanların saptanması, kariyer yollarının alternatifleriyle birlikte gösterilmesi, kariyer planlayıcıların görevlendirilmesi, kişisel kariyer planlarını saptamak ve geliştirmek (Kaynak, 1996: 78).

Bireylerin kariyer planlama sürecinde, birinci ve önemli basamak hedefini belirleme ve karar verme aşamasıdır. Kariyer seçimi insan yaşamında çok uzun bir döneme hitap edeceği ve bununla yaşanılacağı için çok önemlidir (Becker, 1960: 32-40). Son zamanlarda bireyler meslek seçimini yaparken büyük çoğunlukla kendi ilgi, yeteneklerine uygun olandan ziyade kendilerine rahat bir hayat sürdürebilecek, maddi getirisinin yüksek olduğunu düşündüğü meslekleri seçmektedirler. Bu da bireylerin her ne kadar getirisi yüksek olsa bile tam olarak mutlu olmasını, işinden keyif almasını engellemektedir (Du Brin, 1988: 533).

Bireyin içinde yaşamış olduğu aile, ailenin sosyal ve ekonomik durumu ve bireyin yaşamış olduğu çevre bireyin kariyer seçimine etkisi bulunan temel toplumsal faktörlerdir. Birey içinde yaşamış olduğu, etkileşim halinde olduğu çevreden çok şey öğrenir. Hayata bakış açısı genetiğin yanında yaşamış olduğu çevreden de çok büyük oranda etkilenir. Mesleklerin toplumlara göre statüleri değişkenlik göstermektedir. Bazı mesleklere bazı toplumlarda fazlasıyla ilgi gösterilip, saygı duyulabilirken; toplum değiştiğinde o meslek sıradan olarak görülebilir. Bundan dolayı bireyler kendi toplumlarında kabul görmüş meslekleri seçme eğilimine girerler. Meslek seçiminin bir diğer ayağını ise aile oluşturur. Eğitim seviyesi düşük ebeveynlerin çocuklarının yetenek ihtiyacı olmayan meslekleri seçme ihtimalleri yüksek; eğitimli, yönetici ve uzmanların çocuklarınınsa daha çok uzmanlık ve beceri ihtiyacı olan mesleklere doğru bir yönelim gösterdikleri söylenebilir (Can ve diğg.., 2001: 122). Çünkü, bireylerin yaşamış oldukları sosyal çevreden, ailesinden ve gittiği okuldan öğrendiği düşünce ve inanışların kariyer tercihinde çok önemli bir yeri vardır.

Gerçekte bireyler edinmiş oldukları değerlerde değişime gitme konusunda zihinde çok şiddetli bir çatışma yaşarlar. Beklentiler maddi ya da manevi olabilir. Tarihsel zamanın ve kuşağın farklılaşarak değişmesi bu ümitleri tamamen etkileyebilir. Artık yaşanılan zamanda ortaya çıkan çalışma ilişkileri ve yaşam koşullarından dolayı kariyer seçiminde; maddiyat, güç ve ün gibi maddi beklentiler ön planda tutulmaktadır. Bu şekilde tercihte bulunan bireyler terfi imkânına sahip olunan meslekleri tercih etmeye daha fazla eğilim göstermektedirler (Higgins ve diğ. 2003: 102).

Kariyer tercihinde bireyin karakteri de çok büyük önem arz etmektedir. Bireylerin kendi karakter ve yetenekleriyle ilgili olan mesleklere daha fazla eğilim gösterdikleri iddia edilmektedir (Aytaç, 1997: 112). Kişinin karakter ve ilgisinin incelendiği ve bilinen en önemli araştırmalardan bir tanesi John Holland tarafindan literatüre kazandırılan 'Tipolojik Kişilik Kuramı'dır. Bu kuramda altı tane birbirinden farklı karakter yapısı bulunur ve kişiler kendi karakterleriyle aynı doğrultuda ve uygun olan iş kollarına yönelirler. Kişinin karakteri kariyer tercihinin en önemli belirleyicisi değildir. Eğer karakter ve kariyer tercihi arasında bir kesişme bulunursa kişilerin tercihlerini değiştirme ihtimalleri çok düşüktür (Arnold, 1988: 75).

Aşağıda Şekil 3'te de görüleceği gibi, Holland'a göre meslek seçimleri kişiliğin bir ifadesidir ve buna bağlı olarak; gerçekçi, araştırmacı, sanatçı, sosyal, girişimci ve gelenekçi kişilik tipleri söz konusudur. İnsanlar bu altı tipten biri ile karakterize edilebilirler ya da insan altı tipten birine benzer ve her bir kültürün, akranların, ebeveynlerin, sosyal sınıf ve fiziksel çevrenin etkileşiminin ürünüdür. Bireyler bu grupların niteliklerine uygun mesleklerde, çevrede mutlu ve başarılı olabilirler. Başka bir deyişle, kişilik ile mesleklerin yürütüldüğü çevre veya mesleklerin gerektirdiği faaliyetler arasında anlamlı bir ilişki vardır. Her bir çevre belli bir kişilik tipinin başat olduğu bir ortamdır. İnsanlar kendi değerlerini, inançlarını, yeteneklerini, ilgilerini ifade edebilecekleri çevreler ararlar ve tipleri bir araya gelerek kendi temsil ettikleri tipi yansıtan bir çevre yaratırlar. Sözgelimi, sanatçı çevre sanatçı tipindeki insanların bulunduğu bir çevredir ve sanatla ilgili konularla ilgilenirler. $\mathrm{Bu}$ çevrelerde tiplerinin özelliklerine uygun faaliyet olanakları oluşturulmuştur ve tipe özgü faaliyetler pekiştirilmektedir (Kuzgun, 2014: 148). 


\section{Şekil 3:Kişilik Tipleri}

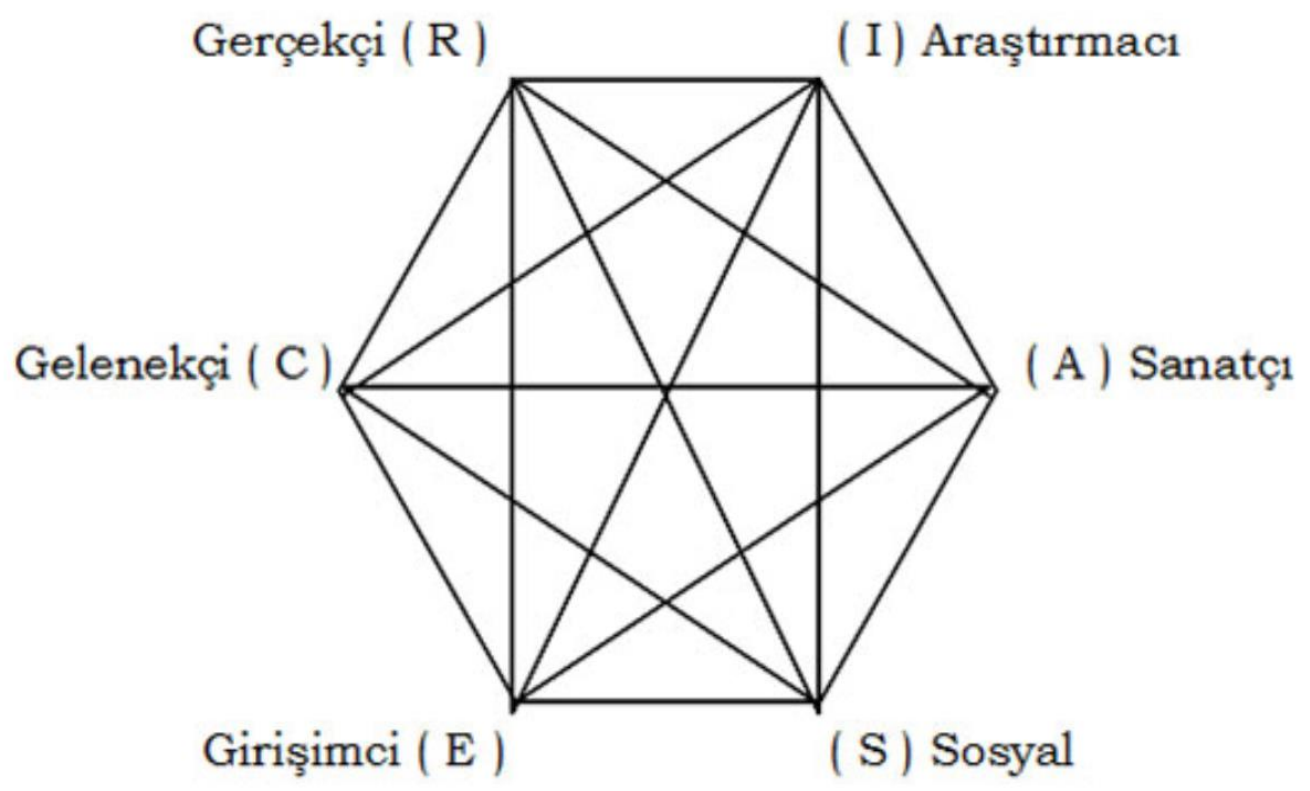

Kaynak: Kuzgun, Y. (2014). Meslek Gelişimi ve Danışmanlığı, Nobel Yayınları, Ankara.

Bireylerin meslek seçimini etkileyen önemli etmenlerden bir tanesi de mesleğin geleceğidir (Özen, 2011: 87). İleriki yıllarda mesleğinin durumunun ne olacağ 1 , hala geçerli bir meslek olup olmayacağı birey adına son derece önemlidir. Eğer geçerliliğinin yitirileceği düşünülürse kişinin bu mesleği seçmekten vazgeçme ihtimali söz konusu olacaktır.

Kısaca, kariyer ve kariyer plânlaması kavramları kişi ve örgütler açısından artık üzerinde önemle durulan kavramlardır. Kişinin kariyeri ve bu konudaki çalışmalar, hem kişilerin ihtiyaçlarının ve beklentilerinin yerine getirilmesinde ve heveslendirilmesinde, hem de gerçekleştirilmeye çalışılan amaçların başarılı olması bakımından son derece önem arz etmektedir. Bu bağlamda kariyer plânlaması; çalışan bireylerin, karşılarına çıkacak fırsat ve yolları, bunların sonuçlarının farkına varmalarını, kariyer tercihlerini ve hedeflerini belirlemelerini, belirledikleri bu hedefleri gerçekleştirmede yol ve zamanın farkına varmalarını sağlayarak her türlü gelişimsel faaliyetleri düşünmelerini ve programlamalarını kolaylaştırır (Anafarta, 2001: 2-9). Bundan farklı olarak kariyer planlaması, kişilerin değer ve gereksinimleri ile mesleki tecrübeleri ve bu tecrübelerin getirmiş olduğu firsatlar arasında en uygun durumları bulmayı hedefleyerek çözüm odaklı bir karar verme süreci oluşturur (Kordon, 2006: 122).

Bireyler, meslek hayatlarında hangi seviyede olduklarını, neleri gerçekleştirebildiklerini ve gelecekte neleri yapabileceklerinin ne kadar farkında olurlarsa amaçladıkları yere o kadar kolay geleceklerdir. Bunun en önemli basamağı bu farkındalıklar üzerinde olabildiğince kişinin kendisini geliştirmesi, bu amaç uğruna elinden ne geliyorsa yapması ve sürekli çalışmasıdır. Bireye bu imkânı veren en önemli olgu kariyer planlama sürecidir.

Yapılan bu açıklamalardan hareketle kariyer planlaması ve sürecinin hem kurum ve örgütü hem de bireyi yani çalışanı doğrudan etkilediği söylenebilir. Kariyer tercihlerinde, planlanmasında ve bunun yönetiminde hem kişinin hem de örgütün kendilerine göre sorumlu olduğu alanlar birbirlerinden tamamen farklıdır. Burada önemli olan en temel aşama bireyin amaç ve beklentileri ile örgütün veya kurumun beklentileri arasında çok dikkatli bir denge oluşturmaktır. Eğer bu şekilde bir denge oluşturulacak olunursa bu her ikisini de olumlu anlamda etkileyecektir.

\section{POLITIK DAVRANIŞLARIN KARIYYER PLANLAMA ÜZERINE ETKİSI}

Çalışanların kariyer hedefleri, güdüleri, ihtiyaçları, cinsiyetleri, çalıştıkları kuruma yapmış oldukları yatırımlar ve kişilik özellikleri önemli öncellerdir. Örgütte faaliyet gösteren bireylerin kullanmış oldukları politik stratejiler, performans değerlendirme, maaşta iyileştirme ve çalışmış olduğu birimde yükselme gibi bireyin kariyeri açısından önemli görülen; insan kaynaklarına temel oluşturacak kararları önemli oranda etkiler. Çalıştıkları kurumlarda iyi bir kariyere sahip olmak isteyen bireyler, insan kaynakları ve politik davranışların birbirini ne kadar etkilediğini fark eder ve politik davranışta bulunmaya daha fazla önem verirler.

Ferris ve King (1991) karşısındakini etkileyip, isteklerini gerçekleştirme becerisine sahip bireylerin, karar verme durumlarının belirsiz olduğu ortamlarda, amirlerini ya da yöneticilerini etkileyerek, alınacak personelin 
seçimi, personelin performansını belirleme ve biriminde yükselme gibi kararlara etki edebileceklerini belirtmektedirler. Aynı şekilde Dulebohn ve diğ. (2009) çalışmalarında amirlerinin göze girme stratejisini kullanan bireylerin performans belirleme ve değerlendirme zamanlarında daha iyi puanlar aldıkları sonucuna ulaşmışlardır. Bartol ve Martin de (1990) çalışan bireylerin amirlerden birini veya birkaçını tanıyor olmaları ve işten ayrılacaklarına dair tehditte bulunduklarında amirlerin maaşlardaki iyileştirmelerde taktiği uygulayan kişinin yani çalışanın lehinde karar verdiği sonucuna ulaşmışlardır. Thacker ve Wayne (1995) de mantıkla ikna stratejisini uygulayan bireylerin biriminde yükselme değerlendirmelerini yani terfi kararlarında olumlu etkiye sahip olduğu sonucuna ulaşmışlardır. Orpen (1996), toplamda 137 amire uyguladığ1 politik stratejiler ve başarılı kariyer arasındaki ilişkinin araştırıldığı incelemesinde göze girme stratejisi ile maaşta iyileştirmeler ve kariyerinde yükselme arasında olumlu bir ilişki bulunduğunu tespit etmiştir.

Wayne ve diğ. (1997)'de amirlerin örgütte faaliyet gösteren bireylere yönelik algılarının politik davranışlardan etkilendiğini bulmuştur. McFarland ve diğ. (2002) çalışan bireyler üzerinde bunların terfileriyle ilgili yaptıkları araştırmada terfi için değerlendirmeye alınan bireylerin uygulamış olduğu politik davranışların değerlendirme sonuçları üzerinde yine pozitif bir etkisi olduğu sonucuna ulaşmışlardır. Bütün bu araştırmalar göstermektedir ki politik taktikleri uygulayan bireylerin, yöneticilerin çalışanlar üzerindeki algılarını değiş̧irdiğini ve çalışan kişilerle ilgili alınacak olan kararların pozitif olarak etkilendiğini göstermektedir.

Politik davranışların insan kaynakları yönetimi alanında etkili olduğunu öne süren çalışmalar incelendiğinde, kariyer hedefleri yükssek olan çalışanların bu tip yöntemleri kullanma ihtimallerinin daha yüksek olduğu görülmektedir (Todd ve diğ. 2009: 188). Politik yol ve yöntemleri kullanan kişilerin kurum içerisinde daha başarılı ve üretken oldukları gözlemlendikçe kurum içerisindeki diğer iş gücünün de bu kişileri model alma ihtimalleri artmaktadır. Zanzi, Arthur ve Shamir (1991) göreve yükselme, maaşlarda iyileştirme ve örgüt içerisinde daha sözü geçen, etkili ve güçlü olmak gibi dışsal başarı metotlarını benimseyen çalışanların, kişisel yeteneklerini geliştirme ve bireysel çalışma gibi içsel başarı faktörlerini hedef olarak benimseyen çalışanlara göre daha fazla politik davranışlar sergilediklerini söylemektedirler. Bu bağlamda dışsal başarı faktörlerini amaç olarak edinen kişilerin özellikle iletişim ağı kurma, mantıkla ikna ve destek oluşturma gibi yöntemleri daha çok kullandıklarını ileri sürmektedirler.

Seibert, Kraimer ve Crant da (2001) araştırmalarında iş hayatında kariyer gelişimleri için bilerek veya farkında olmadan, sonucu ne olursa olsun çok farklı sonuçlar oluşturmak ya da mevcut durumda bulunan koşulların işleyişini değiştirmek için inisiyatif kullanmayı tercih eden bireylerin politik davranışlar sonucunda iki yıllık bir zaman zarfında aldıkları maaş zammı ve terfileri pozitif olarak etkilediklerini bulmuşlardır.

Yapılan tüm bu araştırma ve incelemelere bakıldığı zaman örgütlerde politik davranışların ne denli etkili olduğu ortaya çıkmaktadır. Kariyer gelişimi ve planlaması adına da rol-model olma açısından son derece önemlidir. Politik davranışlar kullanarak kişisel hedeflerine, çıkarlarına ulaşan bireyler örgüt içinde fark edildikçe diğer çalışanlar veya örgütte bulunan diğer bireylerde bu kişileri örnek alma ve taklit etme eğiliminde olacaklardır. Çünkü bunun başarıya ulaştıran bira araç olduğunun farkına varacaklardır. Yapılan tüm araştırmalar uygulanan politik taktiklerin farklı farklı etkilerinin olduğunu da göstermektedir. Her durumda her politik taktik işe yaramamaktadır.

Politik taktiklerin ne kadar uygulandığından ziyade politik taktiklerin ne denli başarıya götürdüğünün önemi vardır. İşte bu durumda ne kadar başarıya götürdüğü görülür ve fark edilirse örgüt içerisinde bulunan birey tarafından model olma ihtimali o denli artacaktır. Yani birey kariyer planlamasını yaparken bu taktikleri kullanacak ve başarıya ulaşacağını bilecektir.

\section{SONUÇ}

Örgütler, ne sadece etkinlik, verimlilik, kalite, yenilik doğrultusunda, hedeflerine varmak için, rasyonalitenin ve rasyonel davranışların söz konusu olduğu bir mekanizma, ne de bazı eleştirel yönetim kuramlarında sözü edilen, sınıf çatışmaları üzerine inşa edilmiş süreçlerin oluşturduğu yapılardır. Örgütler bu süreçlerin her ikisinin de kesişiminde yer alan, iç ve diş çevre dinamiklerine uyum sağlayabilmek için işleyişlerinde informel ilişkilerin söz konusu olduğu tarafların ve ilişkili aktörlerin birbirleri ile güç mücadelesine ve pazarlığına giriştiği, üyelerinin kişisel çıkarları uğruna stratejik ve politik yöntemlerin her daim kullanıldığı dinamik mekanizmalardır. Bu çerçevede, örgütsel davranışların en temel dinamiklerinden olan güç ve onun somut eylemi olan politik davranışlar ve bu amaçla geliştirilip uygulanan yöntem ve stratejiler kuşkusuz örgütlerin varlıklarının temel gerçekliği olarak her aşamada kendisini hissettirmektedir.

Toplum halinde bulunan ve örgütsel ilişkiler geliştirmek durumunda bulunan bireylerde rol ve model alma davranışlarının söz konusu olması bir ölçüde kaçınılmazdır. Öğrenilen her şey aslında bir model alma davranışıyla gerçekleşmektedir. Yaşları ilerledikçe model alınan davranışlarda ve bakış açılarında farklılıklar oluşur. Bu kez dikkat çeken davranışlar, ilgi çeken hareketler tekrarlanmaya, model alınmaya başlar. Daha 
ileriki yaşlarında ise kendine yarar sağlayan, çıkarlarıyla uyumlu, gelişimine katkısı olabilecek, maddi getiriyi etkileyebilecek davranışları görmeye, onlara dikkat etmeye ve bu davranışlar sonucunda kazanım elde eden kişileri model almaya eğilim gösterilmeye başlanacaktır. İşte tam da burada örgüt içerisinde politik davranışların kariyer planlamaya etkisiyle karşılaş1lır. Kişi politik davranışlarla, bir mevkiye gelen, örgüt içerisinde ön planda olan, terfi almış, maaşında iyileştirme olmuş ve bu gibi getirisi olan kazanımların birisini veya birkaçını bu yöntemlerle elde etmiş kişileri model almaya yeltenecektir ve kariyer planlamasında bu durumları mutlaka düşünme eğiliminde olacaktır. Bunları gerçekleştiren kişiyle yakın olmaya, onun isteklerini yerine getirmeye, ondan bir şeyler öğrenmeye başlayacaktır. Bu kazanımları nasıl elde ettiğini anlamaya çalışıp uygun olan ilk firsatta kendisi kullanmayı öğrenecektir. Bunun bilincinde olan birey, insan kaynakları ve politik davranışların ne kadar pozitif bir etkileşim içinde olduğunun da farkına varmış demektir. Çünkü, doğada olduğu gibi örgüt içinde de çalışanlar, zor bulunan, daha değerli olan ve herkesin sahip olmak istediği kıt kaynaklar için sürekli mücadele halindedirler. Bu eğilim çalışanları birbirleriyle karşılaştırma yapmaya ve sonuçta da rekabet etmeye yöneltecektir (Mintzberg, 1983: 83). Esasında bu rekabetçi etkileşimlerin altında yatan temel dinamik, güç ve güce sahip olma duygusudur. Bu yüzden bir örgüt içinde bulunan bireyler, diğerleri tarafindan kabul görmek ve kendilerine saygı duyulmasını sağlayacak gücü ellerinde tutmak ve bunu etkin kılmak istemektedirler. Sözgelimi örgütte üst seviyelerdeki pozisyonların azlığı ve gelişme için kaynakların sınırlılığı, alt kademelerde çalışanlar arasında rekabetin oluşmasına sebep olacaktır. Bu anlamda bireyin çevresini etkilemek ve diğerlerinin davranışlarını kendi isteği doğrultusunda değiştirmek için güce ihtiyacı vardır ki bu da bireyi politik/stratejik düşünmeye ve davranmaya yöneltecektir.

Örgüt teorilerinin büyük bir kısmı örgüt üyelerinin davranışlarının rastgele olmadığını ve bu üyelerin amaçlarının açık bir şekilde tanımlanmış olduğunu öngörmektedirler. Bu bağlamda söz konusu bu rasyonel yaklaşıma göre örgütsel kararlar rol ilişkilerine bağlı olarak mantıksal olarak verilir. Buna karşın örgüt içi ilişkilere politik çerçeveden bakıldığında üyelerin amaçlara ulaşmak için güç kaynağına sahip taraflar güç elde etmenin pazarlığını yapmaktadırlar. Bu çerçevede örgüt içinde farklı çıkar ve amaçları olan tarafların varlığı kabullenilmektedir (Zaleznik, 1999: 52-69). Bu taraflar, beklentilerini karş1lamak ve kendi güçlerini arttırmak için gerekli olan önlemleri alarak örgüt işleyişini ona göre biçimlendirirler. Örgüt de amaçlarına ulaşmak ve varlığını devam ettirebilmek için bireyleri biçimlendirir. Buna göre üyeler ve örgüt süreç içinde yeniden yapılanırlar. Bu süreç informel yapıların ve ilişkilerin gelişmesine de neden olur. Dolayısıyla bütün örgütlerde biçimsel olan yapının yanında bir de biçimsel olmayan, görünmeyen ama hissedilen bir gölge yapılanma da mevcuttur. Örgüt çalışanlarının çok büyük bir kısmı bu biçimsel olmayan yapının içindeki tutum ve ilişkilere sahiptir ve örgütler gerçekte bu biçimsel olmayan ilişki içinde faaliyet göstermektedirler. Tarafların birbirlerinin davranışlarını istedikleri yönde değiştirme çabası ve pazarlık süreci etkileşimleri bir güç ilişkisi ve buna bağlı olarak örgütsel ilişkilerin politik bir sürece dönüşmesine neden olur. Üyelerin kariyer elde etme çabalarının bu politik sürecin merkezinde yer aldığı varsayılacak olunursa, örgüt içerisinde politik davranışların kariyer planlama sürecinde doğrudan etkisinin olduğu ve insanların örgüt içerisinde her türlü kazanımı elde edebilmek için sürekli politik davranış sergiledikleri söylenebilir. 


\section{KAYNAKÇA}

Allen, R. W., Madison, D. L., Porter, L. W., Renwick, P. A. ve Mayes, B. T. (1979). “Organizational Politics: Tactics and Characteristics of Its Actors". California Management Review, 22 (1). 77-83.

Anafarta, N. (2001). “Orta Düzey Yöneticilerin Kariyer Planlamasına Bireysel Perspektif”, Akdeniz Üniversitesi İ.İ.B.F. Dergisi, 2, 2-9.

Arnold, J. (1998). Work Psychology, G.B: Financial Times Professional Limited.

Aytaç, S. (1997). İş Yaşamında Kariyer Yönetimi, Planlaması, Geliştirilmesi, Sorunları, Epsilon Yayınları, İstanbul.

Bartol, K. M. ve Martin, D. C. (1990). "When Politics Pays: Factors Influencing Managerial Compensation Decisions". Personnel Psychology, 43, 599-615.

Baruch, Y. ve Maury, P.W. (2001). "Career Management Practices: An Empirical Survey and Implications", Human Resource Management, 39 (4), 347-366.

Becker, H. S. (1960). "Notes on the Concept of Commitment", American Journal of Sociology, 66 (1), 32-40.

Budak, G., ve diğ., (2001). İnsan Kaynakları Yönetimi, Barış Yayınları, İzmir.

Bursalı, Y. M. (2008). "Örgütsel Politikanın İşleyişi: Örgütsel Politika Algısı Ve Politik Davranış Arasındaki İlişkiler”, Yayımlanmamıș Doktora Tezi, Dokuz Eylül Üniversitesi, İzmir.

Can, H., ve diğ., (2016) Kamu ve Özel Kesimde İnsan Kaynakları Yönetimi, Siyasal Kitabevi, Ankara.

Canman, A. D. (1995). Çağdaş Personel Yönetimi, TODAİE Yayını, No: 260, Ankara.

Ceylan, S. (2004). "Kamu ve Özel Sektörde Yöneticiye Yönelik Etkileme Taktiklerinin Yönetici Cinsiyeti, Çalışan Cinsiyeti ve Etkileme Taktiklerinin Kullanılma Amaçları İle İlişkisi”, Yayımlanmamış Yüksek Lisans Tezi, Hacettepe Üniversitesi, Ankara.

De Cenzo, ve diğ., (1988). Personnel/Human Resource Management, Englewood Cliffs, NJ: Prentice Hall.

Du Brin, A. J. (1988) “Career Maturity, Organizational Rank and Political Behavior Tendencies: A Correlation Analysis of Organizational Politics and Career Experience", Psychological Reports, 63 (2), 531-537.

Dulebohn, J. H., ve diğ., (2009). "Employee Benefits: Literature Review and Emerging Issues", Human Resource Management Review, 19 (2), 86-103.

Ertürk, M. (1995). İşletmelerde Yönetim ve Organizasyon, Beta Basım Yayım, İstanbul.

Farrell, D. ve Petersen, J.C. (1986). "Patterns of Political Behavior in Organizations", The Academy of Management Review, 7(3), 403-412.

Ferris G. R. ve King, T. R. (1991). "Politics in Human Resources Decisions: A Walk on the Dark Side", Organ Dyn, 20, 59-71.

Ferris, G. R., Fedor, D. B., ve diğ., (1989). "Myths and Politics in Organizational Context”, Group and Organization Studies, 14, 83-103.

Hellriegel, D., ve diğ.,. (2001). Organizational Behavior, South Western College Publishing, USA.

Higgins, C. A. Judge, T. A. ve Ferris, G. R. (2003). "Influence Tactics and Work Outcomes A Meta-Analysis". Journal of Organizational Behavior, 24, 89-106.

İslamoğlu, G. ve Börü, D. (2007). "Politik Davranış Boyutları: Bir Ölçek Geliştirme Çalışması”, Akdeniz Üniversitesi, İ.İ.B.F Dergisi, 7 (14), 135-153.

Judge, T. A. ve Bretz Jr., R. D. (1994). "Political Influence Behavior and Career Success". Journal of Management, 20, 43-65.

Karcioğlu, F. ve Timuroğlu, M. K. (2004). “Örgüt Kültürü ve Liderlik”, Atatürk Üniversitesi İ.İ.B.F. Dergisi, 18 (1-2), 319-338.

Kaynak, T. (1996). İnsan Kaynakları Planlaması, Alfa Yayınları, İstanbul.

Kipnis, D., Schmidt, S. M. ve Wilkinson, I. (1980). "Intraorganizational influence tactics: Explorations in getting one's way". Journal of Applied Psychology, 65(4), 440-452.

Koçel, T. (2001). İşletme Yöneticiliği, Beta Basım Yayım, İstanbul.

Kordon, E. (2006). "Yetkinliklere Dayalı Kariyer Plânlama ve Endüstri Mühendisliği Öğrencileri İçin Bir Uygulama", Yayımlanmamış Yüksek Lisans Tezi, Pamukkale Üniversitesi, Denizli.

Kuzgun, Y. (2014). Meslek Gelişimi ve Danışmanlığı, Nobel Yayınları, Ankara.

Malinowski, B. (1990). İnsan ve Kültür, (Çev. Fatih Gümüş), V Yayınları, Ankara.

Mayes, B. T. ve Allen, R. W. (1977). "Towards A Definition of Organizational Politics", Academy of Management Review, 2 (4), 672-678.

Mayes, B. T. ve Ganster, D. C. (1988). "Exit and voice: A test of hypotheses based on fight/flight responses to job stress". Journal of Organizational Behavior, 9(3), 199-216.

McFarland, L. A., ve diğ., (2002). "Field Study Investigation of Applicant use of Influence Tactics in a Selection Interview". The Journal of Psychology, 136, 383-398.

Miles, R. (1980). Macro Organizational Behavior, Scot, Foresman, Michigan.

Miller, R. ve Kurchner-Hawkins, R. (2004). “Organizational Politics: Positive Strategies for Turbulent Times”, ASTD 2004 International Conference Exposition, 1-9.

Mintzberg, H. (1983). Power in and Around Organizations. Englewood Cliffs, Prentice-Hall, NJ.

Murray, V. ve Gandz, J. (1980). “Games Executives Play: Politics at Work”, Business Horizons, 23, (6), 11-24. 
O’Neil, J. (2004). "Effects of Gender and Power on PR Managers' Upward Influence”, Journal of Managerial Issues, 16, $127-144$.

Orpen, C. (1996). "The Effects of in Gradation and Self-Promotion Tactics on Employee Career Success". Social Behavior and Personality, 24, 213-214.

Özen, Y. (2011). "Kişisel Sorumluluk Bağlamında Kariyer Seçimini Etkileyen Sosyal Psikolojik Faktörler”, Eğitim ve İnsani Bilimler Dergisi: Teori ve Uygulama, 2 (3), 81-96.

Peled, A. (2000) "Politicking for Success: The Missing Skill”, Leadership \& Organization Development Journal, 21 (1/2), 20-29.

Pettigrew, A. M. (1973). “Occupational Specialization as an Emergent Process” The Sociological Review, 21 (2), 255 272.

Robbins, S. P. ve Judge, T. A. (2017). Organizational Behavior, Pearson, Boston.

Seibert, S. E, Kraimer, M. L. ve Crant, J. M. (2001). "What do Proactive People do? A Longitudinal Model Linking Proactive Personality and Career Success". Personnel Psychology, 54, 845-874.

Sonaike, K. (2013). "Revisiting the Good and Bad Sides of Organizational Politics". Journal of Business \& Economics Research (JBER), 11(4), 197-202.

Thacker, R. A. ve Wayne, S. J. (1995). "An Examination of the Relationship Between Upward Influence Tactics and Assessments of Promotability". Journal of Management, 21(4), 739-757.

Todd, S. Y., ve diğ., (2009). "Career Success Implications of Political Skills". The Journal of Social Psychology, 149, 179-204.

Tokat, B. ve Aşkun, C. İ. (2003). İşletmelerde Yönetim ve Örgüt, Eğitsel Yayınları, İstanbul.

Tuschman, M. (1977). A Political Approach to Organization: A Review and Rationale" Academy of Management Review, 2, 206-216.

Wayne, S. J. ve Ferris, G. R. (1990). "Influence Tactics, Affect, And Exchange Quality In Supervisor-Subordinate Interactions: A Laboratory Experiment And Field Study”. Journal of Applied Psychology, 75(5), 487.

Wayne, S. J., Liden, R. C., ve diğ., (1997). "The Role of Upward Influence Tactics in Human Resource Decisions". Personnel Psychology, 50, 979-1006.

Yukl, G. ve Falbe, C. M. (1990). "Influence Tactics and Objectives in Upward, Downward, and Lateral Influence Attempts". Journal of Applied Psychology, 75(2), 132-140.

Zaleznik, A. (1999). "Power and Politics in Organizational Life". The McKinsey Quarterly, 7 (4), 52-69.

Zanzi, A., Arthur, M. B. ve Shamir, B. (1991). "The relationships between career concerns and political tactics in organizations". Journal of Organizational Behavior, 12(3), 219-233. 